\title{
COVID-19 and consumer financial vulnerability
}

\section{Johan van OPHEM}

\section{Wageningen University \& Research, The Netherlands}

Abstract:

Aim: This paper provides an overview of the impact of COVID-19 on consumer (household) financial vulnerability in the Netherlands in the context of socio-economic developments for households in the period 2008-2016.

Design/ research methods: After a discussion of the socio-economic developments for household in the period 2008-2016, financial vulnerability analytics is used to discuss the implications of the published results of two surveys on the impact of COVID-19 on the financial situation of households in the Netherlands (AFM/CPB, NIBUD).

Findings: It appears that problems are to be expected in households with uncertain incomes (e.g., flex workers and self-employed), in households with inflexible budgets (with fixed and necessary expenses higher than disposable income), in households that are fragile because of lack of buffers, and in households with a low income for a longer period of time. Some households such as the ones of singles and the young are less able to cope with the financial risks than others. There are lifecycle effects to be noted: the young will have difficulty in finding and keeping jobs, and therefore in making ends meet.

Value of research: The analytics and results are of interest and relevant for cross-cultural research in other Western Countries.

Keywords: Corona, COVID-19, financial vulnerability, income decline; unemployment

JEL: D11, D14

Correspondence address: Johan van OPHEM, Wageningen University \& Research, Droevendaalsesteeg 4, 6708 PB Wageningen, The Netherlands. E-mail: johan.vanophem@wur.nl; info@jacvanophem.nl. Received: 30.10.2020, Revised: 17,12,2020, Accepted: 18.12.2020

doi: http://dx.doi.org/10.29015/cerem.894 


\section{Introduction}

Since the beginning of 2020, due to the COVID-19 virus many people died. On a global scale, lockdowns of economic activities, especially in recreation, culture, sports and tourism, were applied. For many working from home became the rule, whereas others were confronted with the closure of restaurants, schools and universities. Contrary to the Great Recession (2008-2016), austerity is not applied in economic policy now. In the Netherlands various kinds of government support exist to prevent a total collapse of the economy.

The lockdown applied as a consequence of the first wave of COVID-19 led to a decline in GDP ranging from -9 to -20 per cent in OECD countries in the second quarter of 2020. In the last part of 2020 and beginning of 2021 many bankruptcies are expected to occur across the western world as a result of the second wave. However, as we can read in OECD (2020a), for the first time since the pandemic began, there is now hope for a brighter future thanks to the development of vaccines,

with the global economic growth to be expected to vary between 5 per cent (optimistic scenario) and 2.75 per cent in 2021 (pessimistic scenario). Nevertheless, the outlook continues to be exceptionally uncertain, with both upside and downside scenarios (OECD 2020a).

The lockdown implies rising unemployment rates and decline of real income for many households. The population with paid work will be more affected by COVID19 in the decline in income (unemployment) than the population without a paid job. This growing consumer and household insecurity leads to more financial vulnerability.

The topic of this paper is the impact of COVID-19 on financial vulnerability of consumers or households. Financial vulnerability refers to consumer situations that may lead to the endangerment of income security or level of living of the household in the longer run. We will restrict the empirical part to data on the Netherlands, a country with generous programs of government support to households and firms in the first wave of COVID-19.

In section two we will give background information on the economic setting of household in the Netherlands. We will be setting the scene by showing that in the 
period 2008-2016 consumer vulnerability increased, e.g., due to the elimination of buffers and automatic stabilizers. In section three we will develop a theoretical framework that will be used to analyse the data of two studies among the population with paid work in section four. The last section contains the conclusion and discussion.

\section{Economic setting of households in the Netherlands}

Table 1 provides socio-demographic information on households in the Netherlands. In about 5.2 million on a total of 7.9 million households at least one person has paid work. About 30 per cent of the workers belong to the flexible workforce. There are about 3.5 million singles and there about 4.5 million couples, about half of them with children.

Table 1. Socio-demographic information on households in the Netherlands some statistics on households

Some statistics on households

- 7.9 million households.

- 5.2 million household with at least a working breadwinner.

- About 2 million households with a retirement pension.

- 3.5 million one person households (singles).

- About 558,000 one parent households.

- About 2.1 million couples with children.

- About 2.2 million couples without children.

- The average household net adjusted disposable income per capita is USD 29,333 a year, lower than the OECD average of USD 33,604.

- The average household net wealth is estimated at USD 157, 824, lower than the OECD average of USD 408,376.

- Dutch people earn USD 52, 877 per year on average, more than the OECD average of USD 43,241 .

-30 per cent of workforce are flexible workers (flex workers and self- employed).

Source: data collected by author from CBS Statline (2020); international income figures from OECD (2020b).

In 2008 and 2009, the first years of the Great Recession, expansionary policies, i.e., spending more, taxing less, printing money, were used to combat the crisis. In short, the text book solution. But since 2010 the so-called Austerians reigned: fiscal 
austerity instead of fighting unemployment. Debt, both private and public, is seen as the main problem. The Austerian desire is according to Krugman (2012) deeply destructive, as it pays little or no attention to the spread and dangers of unemployment. In the Keynesian approach, the budget deficit is in the first place less important than the unemployment level and, consequently, full employment or higher unemployment is expected to diminish the budget deficit of the government. Modern monetary theory learns that the quest for a small government budget is not necessary from a monetary point of view and, furthermore, hinders societal progress in many ways (Kelton 2020).

Unemployment in the Eurozone was higher than in the EU28. In the Eurozone, a low inflation rate is more important than the unemployment rate. This is a consequence of the 3 per cent (government budget deficit) and 60 per cent (government debt) rules in the Eurozone. One of the observations is that Austerity leads to higher unemployment rates than is the case with Keynesian policy (Stiglitz 2016). During the Great Recession, the North-West of Europe suffered less than the south of the Eurozone in terms of unemployment (Eurostat 2018).

An international comparison with seven other Western countries - Canada, Denmark, Finland, France, Germany, UK and USA in the period 2002-2016 - shows that the Netherlands scores the lowest on per capita private consumption, real individual private consumption, real income growth, real house prices, share of labour income, and has the highest tax burden as a percentage of net disposable income (Keus, Verbruggen 2017).

In the period 2008-2018, the following picture arose. High and rising taxes for less public consumption. High taxes on purchase of cars, use of cars, electricity (38 per cent). Automatic stabilizers such as unemployment benefits and some care expenditures were reduced in power. Collective expenditures went up from 38.4 per cent of GDP in 2011 to about 39 per cent in 2013/2014 and about 40 per cent in 2020 (CBS 2020).

Capital income - a source of income for the very rich (top 1 per cent) - is hardly taxed in most Western countries. For example, capital gains in the Netherlands had a flat tax of effectively 1.2 per cent until 1-1-2017 (CBS 2020, own calculations based on tax rules). The effective tax on capital income is about 10 per cent, much lower 
than the 35-40 per cent on labour income. Tax burden has shifted from capital to labour income. In contrast to the low Gini coefficient for income inequality of about 0.30, the one for net wealth inequality is high, 0.8 to 0.9 (CBS 2020). Wealth tax records show a substantial decline in wealth inequality up to the 1970s and a gradual rise thereafter (van Bavel, Frankema 2018; van Bavel 2016). This has also to do with the fact that the return on shares is high as a consequence of low interest rates. Some people speak of the profit shares bubbles. Consequently, the share of capital income in GDP is rising.

Private wealth inequality is already high and becoming more severe in the Western World. Piketty demonstrates this with the following picture: 50 per cent of households owns almost no wealth; 40 per cent owns a house; 10 per cent owns a house and other forms of wealth; and 1 per cent is very wealthy. Moreover, he demonstrates that the private wealth distribution nowadays is as unequal as in 1914 (Piketty 2014).

In the Netherlands, progressive taxation has been virtually abolished (40 per cent and 49 per cent income tax bracket and a VAT tariff of 9 and 21 per cent). According to Piketty (2019), the middle class pays the most of the taxes. The Panama papers in 2015 pointed at tax avoidance and tax evasion by the top 1 per cent, which is facilitated by tax legislation in the West, especially in the Netherlands (Obermaier, Obermayer 2017).

The Great Recession was a very severe recession even in the Netherlands. Austerity led to many deficiencies for households such as a shortage of houses (2011-2014 were very bad years for the construction industry). The pressure on incomes and increased vulnerability put a lot of strain on households in times of COVID-19. Just as in the USA a secular stagnation of household incomes is observed, together with financial insecurity. Many households are problematically indebted. In 2000, 20 per cent of Dutch households encountered difficulties in making ends meet. This percentage increased to 30 per cent in 2015 and somewhat more in 2020 (NIBUD 2019, 2020) This trend has led to concerns about the endangered middle class (Engbersen et al. 2017). 


\section{Theoretical background on households and financial vulnerability}

Every household may be confronted with financial risks. In welfare states there are some collective regulations to mitigate those risks and to provide some social protection. On top of this many households have their own arrangements such as a savings buffer. Some households are better able to cope with financial risks than other and will not be confronted with financial difficulty very rapidly. However, this does not hold for financially vulnerable households. The higher the vulnerability measured on a continuum, the higher the risk of getting into financial trouble.

Financial vulnerability refers to situations that may lead to the endangerment of consumer income security or level of living in the longer run. People do not like this. They want to attain and maintain a certain level of living that is assumed to be normal in society. A loss of the same amount of income (a loss) leads to a greater negative change in welfare than a positive change by an equivalent rise in income (a gain) (see e.g. Knetsch 2016). Table 2 gives an overview of factors that have a positive impact on financial vulnerability of households. Consumer pessimism can be seen as the outcome of financial vulnerability.

\section{Table 2. Factors affecting financial vulnerability of households}

Financial vulnerability increases when

- there is less flexibility in the household budget;

- more consumer fragility;

- more uncertainty in income procurement;

- low income for a longer period of time;

- consumer credit problems.

Source: see van Ophem $(1988,1990)$.

Flexibility in the household budget affects financial vulnerability in several ways. The higher the flexibility or discretionary income, the higher the flexibility in expenditures. This means that expenditures may be postponed (van Raay 2012, 2016). The higher the flexibility or discretionary income, the higher the saving and increase of savings account (savings buffer). A higher share of fixed expenditures in income means less flexibility and higher financial vulnerability. A part of the daily expenditures can be seen as necessary, and thus fixed expenditures, such as food and nutrition, mobility and clothing. It is important to note that the share of fixed and 
necessary expenditures in income has grown in the past decades in the Netherlands, whereas this share is higher for low income groups compared to higher income groups. For instance, in 2013 the lowest 20 per cent income group spent 55 per cent of their income on housing, water, energy, food and beverages, whereas 37 per cent is the corresponding figure for the highest 20 per cent income group (CBS 2016a).

The second factor presented in Table 2 is the financial fragility of households. Research in this field was conducted by Lusardi et al. (2011) in the USA by asking people how confident they are that they could come up with 2,000 dollar (about $€ 1,700)$ if an unexpected need arose within the next month. The following answers were possible: I am certain I could come up with the full 2.000 dollar; I could probably come up with 2.000 dollar; I could probably not come up with the full 2.000 dollar; I am certain I could not come up with 2.000 dollar.

The result for the USA are startling: 28 per cent of the respondents was certainly not able to cope and 22 per cent probably not. The research was also carried out in a cross cultural setting across eight countries. There some striking differences were observed: in the Netherlands about 59 per cent is certainly able to cope, predominantly by drawing on savings ( 89 per cent of this group). In countries as the USA, UK, Canada, Italy, you get different results. Household in the USA and UK are less able to come up with the amount than household in the Netherlands, a country with one of the highest incidence of savings accounts (Lusardi et al. 2011).

The third factor presented in Table 2 is uncertainty with respect to income procurement. This uncertainty is higher for employees without a labour contract for an indefinite period of time and for self-employed without personnel or staff. Currently, about 30 per cent of the working population in the Netherlands belongs to the flexible workforce (CBS 2020). Both categories need larger buffers (savings) to fill the gap between periods in which the income procurement is low or not existent.

Self-employed are to be found among the low and high income groups. At the bottom of the income distribution uncertainty may lead to precariousness. The precariat is a social class formed by people suffering from precarity which is a condition of existence without predictability or security affecting material or psychological welfare. Table 3 shows some implications inherent to precariousness. 
A lower income for a longer period of time has many implications. It leads to a depletion of the stock of durables, less participation in sports activities and a higher incidence of not getting financially by: around 40 of the low income group has problems in getting by, whereas the corresponding figure of the higher income group is 10 per cent (CBS 2016b).

\section{Table 3. Aspects of precariousness}

"[T]he spread of greater labour market flexibility, greater job insecurity, a greater fragility in relationships and a weakening in the formal provision of social welfare" (Nettleton, Burrows 2001).

"[T] he concepts of precarious housing and precarious employment make direct reference to the marginal position of many households" (Beer et al. 2016).

"[Precarious] employment...is uncertain, unpredictable, and risky from the point of view of the worker" (Kalleberg 2009).

"Precariousness (in relation to work) refers to all forms of insecure, contingent, flexible work - from illegalised, casualised and temporary employment, to homeworking, piecework and freelancing" (Gill, Pratt 2008).

Source: derived from McKee et al. (2017).

People with low income for a longer period of time are financially vulnerable. Their financial reserves are depleted and, as said before, many durables are on the brink of collapsing. Scarcity leads to a tunnel vision and to a smaller bandwidth, which increases the risk of financial problems (see, e.g., Mullainathan, Shafir 2013).

Another aspect of financial vulnerability of households is credits. Credit by households can be divided into credit for investment, like mortgages and study loans, and credit for consumption purposes, like cars and decoration. Some credits do have a collateral, others not. Nowadays, more than 50 per cent of the households in the Netherlands has a mortgage and consumer credit is taken up by about 25 per cent. Defaults with respect to mortgages are very rare in the Netherlands. However, in some cases consumer credit may lead to problematic debts and financial problems. As already discussed in the previous section, in 200020 per cent of Dutch households encountered difficulties in making ends meet, whereas this has risen to 30 per cent in 2015, and 33 per cent in 2020 (NIBUD 2019, 2020). Nowadays, there are more households with difficulties in making ends meet than in the 1980s, both absolutely as relatively, when one compares results in van Ophem (1988) with the ones from NIBUD (2019a). 
Financial risk of households is connected to household types and life cycle. Some household types are less vulnerable than others. Dual breadwinner families are financially stronger than households of one breadwinner or singles. Dual breadwinners are less prone to financial risks (de Hoog, van Ophem 2006). Singles are more often found in the lower part of the income distribution, just as single parent families. Couples with children are more often found in the upper part of the income distribution (CBS 2016c). This is partly due to life cycle effects: singles are mostly young or old, couples with children are in the part of their life where income tends to be higher (see, e.g., Bryand, Zick 2006). Wealth is positively correlated not only with income but with age as well. The situation of the young (20-30) with respect to financial vulnerability is more pronounced. Young households are vulnerable to financial shocks (higher mortgage debts, less pension savings, less free savings in saving accounts).

In the next section we will apply the theoretical framework developed here to analyse the data of two studies among the population with paid work.

\section{Results from two surveys}

Tables 4 and 5 provide information of two surveys on the impact of COVID-19 on the financial situation of households in the Netherlands. They were published by the end of the summer of 2020. The studies are restricted to the population with a paid job, who are directly hit in their income procurement due to the spread of the COVID-19 virus and the actions to combat it. The $\mathrm{AFM} / \mathrm{CPB}^{1}$ study is the most comprehensive one of the two. In none of the studies the Lusardi question (how confident people are that they could come up with 2,000 dollar (about $€ 1,700$ ) if an unexpected need arose within the next month) was asked for.

\footnotetext{
${ }^{1} \mathrm{AFM}=$ Authority Financial Markets. Agency that monitors the behavior of economic agents on financial markets as well as safeguard workable competition; $\mathrm{CPB}=$ Government agency that produces economic analyses and economic forecasts.
} 
The AFM/CPB results are based on applying the micro-simulation model Mimosi (CPB) on $\mathrm{CBS}^{2}$ data of 100,000 households (2016). The effect of the gross income shock on disposable income is simulated taking into account relevant allowances like TOZO (Temporary income support due to COVD-19 for selfemployed based on social assistance), unemployment benefit and social assistance. Information on fixed and necessary expenses is used. Several scenarios are analysed: one for income loss of main breadwinners and one for income loss of partner and supplementary incomes. A share of fixed expenditures in the household budget of 0.5 and higher is seen as an indicator of potential financial stress. Financial stress is very high for households with a share of 0.9 and larger. The so called coping period (uitzingtermijn) is calculated, i.e., the period in which households for which fixed and necessary expenses (like food and nutrition) are higher than disposable income are able to pay the fixed expenses from asset withdrawals. A distinction is made between a short coping period (less than three months to cover the expenditures by asset withdrawal) and a longer coping period (assets withdrawal may take longer than six months). The study provides information about the interplay of factors mentioned in the previous section: share of fixed expenditures, stage in the life cycle, insecurity of earnings (flexible workforce or self-employed) and low income. Table 4 contains key findings from the AFM/CPB study.

\section{Table 4. Key findings from the Stress test households}

- It appears that short coping periods are characterized by high fixed expenditures ratios (>0.5) and 0.9 for the share of fixed expenses including food and nutrition in the household budget.

- Households with a short coping period (<3 months) possess net wealth of about $€$ 737 to 1,242 for self-employed and about $€ 170$ to 410 for employed. The corresponding figures for households with a longer coping period (> 6 months) are $€ 28,000$ and $€ 30,000$ respectively.

- Households with a short coping period have lower disposable incomes, rent more frequently a house, are single or single breadwinner.

- About 100,000 households are not able to pay for their expenses within half a year after loss of work; 73,000 after three months.

- $\quad$ Even with TOZO self-employed are more vulnerable.

- Unexpected outlays may exacerbate the financial stress.

Source: AFM/CPB 2020.

${ }^{2} \mathrm{CBS}=$ Statistics Netherlands. 
About 4 per cent of households with a breadwinner with paid work faces very serious financial stress, defined as households that are not able to pay for their expenses for at least three months after loss of work. This is probably an underestimation because of the time that elapses between applying for and receiving of a social benefit (waiting time). Furthermore, government support is not fully used and unexpected expenses may appear. The latter may jeopardize financial planning and may have a great impact on the financial situation of the household, as has been shown in other studies (van Ophem 1988).

\section{Table 5. Key findings NIBUD poll published in July 2020}

- 41 per cent of flex workers (average income $€ 930$ per month) and 44 per cent of self-employed (average income $€ 1,214$ per month) are confronted with an income decline.

- This decline may lead to immediate financial problems. About a quarter of the respondents say that they do not have a buffer to cover four months of income loss. Furthermore, about half of the respondents reporting an income decline has less than $€ 7,500$ of direct disposable assets.

- 43 per cent of the respondents with an income decline $(n=187)$ are very worried about their financial situation This is much higher than the corresponding e 19 per cent for all respondents. Both categories are equally worried about their health and the health of family and friends, about 58 per cent of all respondents.

- About 33 per cent of the respondents has great difficulties in making ends meet. The corresponding figure for flex workers is 36 per cent, and 24 per cent for employed with an infinite labour contract.

- Respondents who have great difficulties in making ends meet mention reasons such as high fixed expenditures, income loss and low income.

- About 35 per cent of the respondents with great difficulties in making ends meet $(n=404)$ is confronted with payment arrears.

- $\quad$ Cutting on expenditures is practiced by 37 per cent of all respondents, 50 per cent of flex workers and 55 per cent of self-employed.

- NOW (Temporary job retention scheme and income support due to COVD-19 for firms) is used by 20 per cent of the employers and allowance as TOZO by 36 per cent of the respondents, 41 per cent of flex workers and 25 per cent of selfemployed.

Source : NIBUD 2020.

Some of the factors analysed in the AFM/CPB study are also mentioned and discussed in the NIBUD ${ }^{3}$-study from July 2020. This is a survey among 1,991 respondents with paid work who are 18 years and older. In the employment status a

\footnotetext{
${ }^{3}$ Netherland Institute for Budget Extension.
} 
distinction is made between employees with an indefinite and employees with a temporary contract, flex workers and self-employed. Flexibility of the labour contract, fixed expenditures, low income are factors in the analysis of making ends meet. Table 5 contains key findings from the NIBUD poll.

About 33 per cent of the respondents has great difficulties in making ends meet. This is in line with previous NIBUD research (2019). Respondents who have great difficulties in making ends meet mention reasons such as high fixed expenditures, income loss and low income. The lack of financial buffers was mentioned by about 25 per cent of the households. An income decline leads to more worries about the financial situation and to cutting on expenditures.

The NIBUD research also shows the relevance of the factors affecting financial vulnerability of households mentioned in Table 2. Flex workers and self-employed are more hit by an income decline than employees.

\section{Conclusion and discussion}

The impact of COVID-19 on household financial situation depends on the length and size of the recession or depression. Some sectors are or will be more hit than others. There will be shifts in consumer demand due to COVID-19 fear. Less demand for services with close human contact is to be expected. Irrespective of the lockdown of pubs and restaurant consumer behaviour is likely to change. Consumers, especially older people and people with health problems, can be expected to behave very cautiously. In the Netherlands, especially people in Amsterdam will be confronted with a difficult financial situation, since the collapse of tourism to the city.

The OECD economic outlook 2021 summarizes the discussion about the global development of GDP in 2021 as follows: "Vaccination campaigns, concerted health policies and government financial support are expected to lift global GDP by $4.2 \%$ in 2021 after a fall of $4.2 \%$ this year. The recovery would be stronger if vaccines are rolled out fast, boosting confidence and lowering uncertainty. Delays to vaccination deployment, difficulties controlling new virus outbreaks and failure to learn lessons 
from the first wave would weaken the outlook. The bounce-back will be strongest in the Asian countries that have brought the virus under control but even by the end of 2021, many economies will have shrunk from 2019 levels before the pandemic." (OECD 2020a).

The recovery of GDP is predicted to be slow in the Netherlands and the unemployment rate likely to remain high (even expected to increase to 6-6.5 cent despite government supportive policies) (OECD 2020a). Population with paid work is and will be more affected by COVID-19 than the population without paid work. For the former the income decline is higher than the latter who have in general a lower income, although there are retired persons with a higher income. It should be noted that about 30 per cent of the workforce in the Netherlands consist of flexible workers. This percentage has grown in the past twenty years and is one of the highest in Europe (Salverda 2018). This makes the quest for decent work most relevant (see, e.g., Timmerman 2019).

The empirical part of the paper is based on the published results of two surveys for the Netherlands. These results give an intermediate picture of the impact of COVID-19 on the financial vulnerability of consumers. Cross cultural research on this topic which takes into account various welfare regimes, aspects of temporary government support for entrepreneurs and employees, the role of flexible labour market, decent work and factors mentioned in Table 2 is needed. What we have in mind are data that can be found and shared in databases such as the European Social Survey, enabling researchers to use freely original data files on various topics of social research as work, family, health, happiness and the like (ESS 2020). A good example of this type of research can be found in Thompson et al. (2020). Comparing Spain with the Netherlands in 2016, they found that increasing financial insecurity has severe negative effects on mental, physical and social health (Thompson et al. 2020).

Anyhow, COVID-19 is likely to stay in Europe and the USA for a couple of years. So the topic of the paper will be relevant for a longer period of time just as the theoretical framework and conclusions drawn. They may be the basis for hypotheses to be tested in other settings than the Dutch one. 
The two surveys discussed above make the relevance of the financial vulnerability analytics discussed in section three clear. Problems are to be expected in households with uncertain incomes, like the ones of flex workers and of selfemployed; in households with inflexible budgets where, e.g., fixed and necessary expenses (like food and nutrition) are higher than disposable income; in households that are fragile because of a lack of buffers; in households with a low income for a longer period of time. Generally speaking, COVD-19 has a detrimental effect on the financial situation of households with an income procurement depending on paid work.

Serious problems are to be expected for about 4 per cent of households with a main breadwinner with paid work, despite the social safety net. This number is probably an underestimation because government support is not fully used, waiting time for support can be long, and unexpected expenses can mess up the financial situation of households. Income support for households with loss of work and income is offered at a social assistance base. This implies not only means testing of household income, but testing of household wealth as well. Some households may receive a benefit that will be lower than their fixed expenses defined in a narrow or wider sense.

Some household such as the ones of singles and the young, are less able to cope with the financial risks than others. There are lifecycle effects to be noted: young will have difficulty in finding and keeping jobs, and therefore in making ends meet. On top of this, in the Netherlands they have difficulty in finding affordable housing. It should not be overlooked that (increasing) financial insecurity has severe negative effects on mental, physical and social health (see Thompson et al. 2019, 2020). One might argue that a policy restriction to health problems induced by COVD-19 has serious societal opportunity costs. It may increase mental health problems, deteriorate physical health induced by forced idleness, and lead to severe loss of Quality Adjusted Life Years. The last may happen due to insufficient attention to health problems currently not life threatening albeit cause of avoidable mortality in later life (see, e.g., Gupta Strategists 2020). This means that the treatment of COVID-19 patients leads to severe health loss in non-COVID-19 patients given the scarcity of resources. 
In the last paragraph of this paper we will discuss some elements of the issue how to help households that ended up in financial misery. Tax authorities in the Netherlands are notorious in applying the fine on fine method in default payments. Anyhow, situations in which household with financial problems are confronted with fine on fine due to inability to pay the debt should be avoided by simply avoiding the fine on fine method. In doing so the government will be very efficient in avoiding financial problems of consumers. However, this may be difficult to achieve since not only the behaviour of tax authorities stems out of mistrust of the citizen but much of the legislation passed in and approved by Parliament during the past decade is characterised by distrust towards the citizen and by putting a great emphasis on individual responsibility when things go wrong for one reason or the other. Therefore, it is not remarkable that a minority of households with financial problems are applying for help and assistance, mostly at a very late stage (see NIBUD 2019b). This calls for an active policy at the local level to reach these household one way or the other. In doing so, it is of great importance to offer highly indebted households a brighter future that is nearby. They should be out of the financial misery in outmost three years. A partly revolving fund to support and alleviate households with severe financial problems may be a good idea to achieve this aim. This may be supported by budget coaching and other accompanying activities. More generally speaking, household with serious financial problems because of COVID-19 should be assisted and not blamed.

\section{References}

AFM/CPB (2020), Stress test huishoudens, CPB/AFM Corona Publication, The Hague.

Bryant W.K., Zick C. (2006), The economic organization of the household, 2nd ed., Cambridge University Press, New York.

Beer A., Bentley R., Baker E., Mason K., Mallett S., Kavanagh A., LaMontagne T. (2016), Neoliberalism, economic restructuring and policy change. Precarious housing and precarious employment in Australia, "Urban Studies", vol. 53 no. 8, pp. 1542-1558.

CBS (2016a), Welvaart in Nederland 2016, https://www.cbs.nl/nl-nl/publicatie/2016/26/welvaart-innederland-2016 [10.10.2020].

CBS (2016b), Ruim miljoen huishoudens komen moeilijk rond, https://www.cbs.nl/nlnl/nieuws/2016/03/ruim-miljoen-huishoudens-komen-moeilijk-rond [10.10.2020]. 
CBS (2016c), Income and spending, http://visualisatie.cbs.nl/en-GB/visualisation/inkomensverdeling [10.10.2020].

CBS (2020), Statline, https://opendata.cbs.nl/\#/CBS/nl/.

De Hoog K., van Ophem J. (2006), Families and changing life styles, in: Heterodox views on economics and the economy of the global society, Meijer G., Heijman W.J.M., van Ophem J.A.C., Verstegen B.H.J. (eds.), Wageningen Academic Publishers, Wageningen, pp. 143-54.

DNB (2016), Nieuwsoverzicht en archief [12.03.2016].

Engbersen G., Snel E., Kreemers M. (eds.) (2017), De val van de middenklasse? Het stabiele en kwetsbare midden, WRR, Den Haag.

ESS (2020), About the European Social Survey, https://www.europeansocialsurvey.org/about/ [06.12.2020].

Eurostat (2018) Eurostat press release 54/2018 - 4 April 2018.

Gill R., Pratt A. (2008), In the social factory? Immaterial labour, precariousness and cultural work, "Theory, Culture \& Society", vol. 25 no. 7-8, pp. 1-30.

Gupta Strategists (2020), COVID goes Cuckoo. How the March-April 2020 COVID-19 surge overwhelmed Dutch hospitals and undermined regular care, https://gupta-strategists.nl/studies/hetkoekoeksjong-dat-covid-heet [06.12.2020].

Kalleberg A.L. (2009), Precarious work, insecure workers. Employment relations in transition, “American Sociological Review”, vol. 74 no. 1, pp. 1-22.

Kelton S. (2020), The deficit myth. Modern monetary theory and the birth of a people's economy, Public Affairs, New York.

Keus P., Verbruggen J. (2018), https://esb.nu/blog/20037396/nederlandse-economie-middenmoter-inhet-eurotijdperk [06.12.2020].

Knetch J. (2016), Some uses, underuses, and misuses of the findings of disparities between people's valuations of gains and losses, "Apstract: Applied studies in Agribusiness and Commerce", vol. 10 no. 2-3, pp. 7-14.

Krugman P. (2012), End this depression now!, Norton, New York, London.

Lusardi A., Schneider D.J., Tufano P. (2011), Financially fragile households: evidence and implications [with comments and discussion], Brookings Papers on Economic Activity, pp. 83-150.

McKee M., Reeves A., Clair A., Stuckler D. (2017), Living on the edge. Precariousness and why it matters for health, "Archives of Public Health", vol. 75 no. 13, https://doi.org/10.1186/s13690-0170183-y [06.12.2020].

Mullainathan S., Shafir E. (2013), Why having too little means so much, Times Books / Henry Holt and Co., New York. 


\section{COVID-19 AND CONSUMER FINANCIAL VULNERABILITY}

Nettleton S., Burrows R. (2001), Families coping with the experience of mortgage repossession in the

"new landscape of precariousness", "Community, Work \& Family", vol. 4 no. 3, pp. 253-272.

NIBUD (2019a), Geldzaken in de praktijk 2018-2019, NIBUD, Utrecht..

NIBUD (2019b), Financiële problemen 2018, NIBUD, Utrecht.

NIBUD (2020), Coronabarometer. De financiële gevolgen van de coronacrisis voor werkenden, NIBUD, Utrecht.

Obermaier F., Obermayer B. (2017), The Panama papers. Breaking the story how the rich and powerful hide their money, Oneworld Publications, London.

OECD (2020a), Economic outlook December 2020, https://www.oecd-ilibrary.org/sites/39a88ab1en/index.html?itemId=/content/publication/39a88ab1-eno [06.12.2020].

OECD (2020b), http://www.oecdbetterlifeindex.org/countries/Netherlands/ [06.12.2020].

Piketty T. (2014), Capital in the twenty-first century, Belkin Press, Cambridge, MA, London.

Piketty T. (2020), Capital and ideology, Belkin Press, Cambridge, MA, London.

Salverda W. (2018), The Netherlands. Is long term income growth ensuring social convergence with better quality and redistribution? Paper presented at the ILO Conference "Industrial Relations in Europe. Fostering Equality and Cross-Cultural Convergence?”, Paris, 17-18 May 2018.

Standing G. (2016), The precariat. The new dangerous class, Bloomsbury, London.

Stiglitz J.E (2016), The euro. How a common currency threatens the future of Europe, Norton, New York, London.

Thompson K., Wagemakers A., van Ophem J. (2020), Assessing health outcomes in the aftermath of the great recession. A comparison of Spain and the Netherlands, "International Journal for Equity in Health", vol. 19 no. 1, https://equityhealthj.biomedcentral.com/articles/10.1186/s12939-020-01203-6 [22.12.2020].

Thompson K., van Ophem J., Wagemakers A. (2019), Studying the impact of the Eurozone's Great Recession on health. Methodological choices and challenges, "Economics and Human Biology", vol. 35 , pp. 162-184.

Timmerman R (2019), Het werk(t) van alle kanten,pleidooi om werk opnieuw vorm te geven, Timmerman, Houten.

van Bavel (2016), The invisible hand? How market economies have emerged and declined since AD 500, Oxford University Press, Oxford.

van Bavel B., Frankema E. (2018), Wealth inequality in the Netherlands, c. 1950-2015. The paradox of the Northern European welfare state, "Tijdschrift voor Sociale en Economische Geschiedenis", vol. 14 no. 2, pp. 29-62.

van Ophem J.A.C. (1988), Huishoudens en inkomensdaling, Wageningen diss. 
van Ophem J.A.C. (1990), Unemployed breadwinners and money management, in: Verhaar C.H.A., de Goede M.P.M., van Ophem J.A.C., de Vries A., Frisian long-term unemployment, Fryske Academy, Leeuwaden, pp. 107-145.

van Raaij W.F. (2012), Consumer financial behaviour, "Foundations and Trends in Marketing", vol. 7 no. 4 , pp. 231-351.

van Raaij W.F. (2016), Understanding consumer financial behavior. Money management in an age of financial illiteracy, Palgrave Macmillan, London. 